\title{
Presença e ausência do Estado na trajetória da indústria da construção naval brasileira - 1959-1989
}

Alcides Goularti Filho*

\section{Palavras-chave}

construção naval, Estado, planejamento, expansão, crise

\section{Classificação JEL}

N66, N76, L91

\section{Keywords}

shipbuilding, State, planning, expansion, crisis

\section{JEL Classification}

N66, N76, L91
${ }^{*}$ Professor da UNESC/PPGDS, doutor em Economia pela UNICAMP

Pesquisa financiada com recursos do $\mathrm{MCTI} / \mathrm{CNPq}$

\section{Resumo}

A finalidade deste artigo é discutir a atuação do Estado e do planejamento na implantação, na trajetória de expansão e na crise da indústria da construção naval pesada no Brasil, entre 1959 e 1989. O texto está dividido em cinco tópicos. O primeiro discute a implantação da indústria naval pesada dentro dos objetivos políticos e estratégicos do Plano de Metas, seguido pela desaceleração entre 1963-1966, até a transformação da CMM e da SUNAMAM em 1969. Em seguida, evidencia-se o período de consolidação e o rápido crescimento do complexo naval plasmado nos planos de construção naval de 1969 a 1982. No terceiro tópico, discute-se o início da reversão das expectativas tendo em vista as dificuldades em cumprir as metas de crescimento dos planos de 1981 e 1982, associada à crise na SUNAMAM. No quarto tópico, entre 1982 e 1989, enquanto a SUNAMAM agonizava e os canais de financiamento escasseavam, a indústria entra numa rota de desaceleração e desmonte parcial do complexo naval. Por fim, o texto traz breve trajetória comparativa da Marinha Mercante e da construção naval latino-americana.

\section{Abstract}

This article aims to discuss the role of state planning in the setting up, the expansion and the crisis of the heavy shipbuilding industry in Brazil, between 1959 and 1989. The text is divided into five topics. The first discusses the setting up of the heavy marine industry within the political and strategic goals of the Plano de Metas, which is followed by a slowdown between 1963-1966. It ends with the transformation of CMM and of the SUNAMAM in 1969. A period of consolidation then becomes evident, marked by the rapid growth of the naval complex. The latter followed the shipbuilding plans established between 1969 and 1982. In the third topic, we discuss the beginning of the reversal of expectations, caused by the difficulties in meeting the growth goals set in the 1981 and 1982 plans. This is associated with the crisis in SUNAMAM. In the fourth topic, between 1982 and 1989, while SUNAMAM agonized and funding sources grew scarce, the industry enters a downturn route with a partial dismantling of the naval complex. Finally, the text provides a brief comparative history of the Latin American merchant marines and shipbuilding industries. 


\section{1_Introdução}

A construção de embarcações para navegar nos rios, nas lagoas e no litoral brasileiro vem sendo feita desde o final do período colonial. Ao longo do século XIX, desenvolveram-se, nas principais cidades litorâneas, ao lado dos Arsenais de Marinha e junto aos portos marítimos e fluviais, pequenas atividades artesanais e manufatureiras, encarregadas de construir embarcações e fazer reparos nas que transitavam na região.

A maior concentração de estaleiros deu-se no Rio de Janeiro, em torno do Arsenal da Marinha do Rio de Janeiro (AMRJ), na Saúde e na Prainha. Havia estaleiros no outro lado da Baía da Guanabara, em Niterói, na Ponta da Areia e nos arredores. Também havia estaleiros mais equipados, que construíam embarcações a vela, os especializados na fabricação de pequenos navios de ferro e os que atendiam às demandas da Marinha de Guerra. Além desses maiores, outros prestavam serviços ao AMRJ, faziam reparos para as companhias brasileiras e estrangeiras de navegação ou revendiam peças e equipamentos para outros estaleiros (Greenhalgh, 1965).

Durante a segunda metade do século XIX, a frota mercante nacional, que cobria todo o litoral, era composta de embarcações que combinavam vela e vapor, adquiridas de frotas desativadas de companhias estrangeiras ou, quando novas, de estaleiros europeus. Aos estaleiros nativos estava reservada, apenas, a construção de embarcações menores para as companhias de navegação que faziam o transporte de cabotagem de pequeno curso. O longo curso era feito apenas por embarcações estrangeiras. As oportunidades abertas com as encomendas de novas embarcações, feitas pelas companhias brasileiras de navegação de grande porte, eram todas desperdiçadas em favor das estrangeiras. A limitada capacidade tecnológica e financeira do país impedia a formação de um complexo industrial naval (Goularti Filho, 2009).
No século XIX, enquanto a base tecnológica era a madeira, os estaleiros nativos não tiveram problemas em adaptar-se a esse padrão, já que havia o produto em abundância no Brasil. Quando se passou a adotar o ferro, a partir da grande indústria, os estaleiros brasileiros não conseguiram acompanhar o ritmo das mudanças e muitos sucumbiram (Braconnot, 1936). A situação agravou-se ainda mais quando, a partir da segunda década do século XX, o aço e a mecânica elétrica, elementos básicos dos adventos da Segunda Revolução Industrial, passaram a comandar a construção naval. Como o Brasil ainda não havia internalizado em seu território essas inovações, seria impossível desenvolver uma indústria naval moderna e capaz de concorrer com os grandes estaleiros europeus, onde o aço já predominava (Goularti Filho, 2009a).

Essas dificuldades na transição tecnológica alteraram o cenário no aglomerado de estaleiros no Rio de Janeiro, no início do século XX, em que os pequenos desapareceram, e as encomendas e os serviços concentraram-se nos maiores. Destacavam-se três estaleiros de porte um pouco maior: a Companhia Nacional de Navegação Costeira, fundada em 1895 pela Casa Lage \& Irmãos, localizada na Ilha do Viana; a Vicente dos Santos Caneco, fundada em 1886, localizada no Caju; e a Companhia Comércio e Navegação, de 1905, que adquiriu as antigas instalações do Barão de Mauá e fundou, na Ponta da Areia, Niterói/RJ, o Estaleiro Mauá. A Companhia de Navegação Lloyd Brasileiro, a maior do Brasil, fundada em 1890, estatal, também possuiu o próprio estaleiro de reparos situado na Ilha Mocanguê (Telles, 2001). O AMRJ construiu outras instalações, deslocando-se para a Ilha das Cobras, e ampliou sua capacidade produtiva, edificando novos diques e adquirindo equipamentos modernos. Após um longo período sem construir embarcações, de 1890 a 1936, o AMRJ voltou a atender às demandas da Marinha, que fez um 
plano de renovação da sua frota. Mesmo assim, o tamanho das embarcações e sua complexidade eletromecânica ainda eram limitadas, quando comparadas com as construídas nos estaleiros dos países centrais (Mendonça \& Vasconcelos, 1959).

Os três maiores estaleiros, Lage, Caneco e Mauá, incorporaram parte dos adventos da Segunda Revolução Industrial, atendendo às novas encomendas dos armadores nacionais, mas ainda eram penalizados pela falta do principal insumo básico para os modernos navios, o aço. Na verdade, essa era uma deficiência de base da indústria brasileira, que, a partir da década dos anos 30, engendrou um processo de industrialização, mas sofria restrições, dadas as frágeis estruturas técnica e financeira, a falta de comando (acumulação vertical intensiva) e a insuficiência na capacidade para importar os equipamentos e os insumos necessários para a industrialização.

Durante o governo de Getúlio Vargas, houve alguns avanços para reestruturar a Marinha Mercante brasileira, sobretudo após a publicação do Decreto-Lei n. 1.951, de 30 de dezembro de 1939, que inaugurou outro regime jurídico para a navegação, garantindo à União o direito de explorar, conceder e autorizar os serviços da navegação marítima, fluvial e lacustre, consagrando a presença do Estado no setor naval e na navegação. Destaca-se também a criação da Comissão da Marinha Mercante (CMM), pelo Decreto n. 3.100, de 7 de março de 1941, autarquia com autonomia administrativa e financeira à qual competia definir as políticas de orientação, organização e financiamento para a navegação brasileira e a incorporação ao patrimônio do nosso país da Companhia Nacional de Navegação Costeira, em 1942, pertencente à Organização Henrique Lage, que, na época, possuía uma frota em torno de 30 embarcações, sendo muitas obsoletas.

A falta de uma indústria de base e de bancos com capacidade de financiamento de longo prazo atrasou a im- plantação de uma pesada indústria da construção naval no Brasil. No final dos anos 40, a Companhia de Navegação Lloyd Brasileiro, a maior empresa do ramo no país, fez uma grande encomenda de navios aos Estados Unidos, adquirindo embarcações usadas, que poderiam ser construídas no Brasil, caso aqui houvesse uma indústria da construção naval moderna (Goularti Filho, 2009b). O mesmo ocorreu durante a execução do Plano SALTE (Saúde, Alimentação, Transporte e Energia), quando foram adquiridas três novas embarcações para o Serviço de Navegação da Amazônia e a Administração do Porto do Pará (SNAAPP) (Costa, 1971). No estudo elaborado pela Comissão Mista Brasil/Estados Unidos (CMBEU), também estava prevista a compra de novas embarcações no exterior, para renovar a frota da Navegação Costeira, da Companhia Comércio e Navegação e do Serviço de Navegação da Bacia do Prata (SNBP) (Comissão Mista Brasil Estados Unidos, 1954). Mesmo não sendo executados os dois planos na sua plenitude, ambos reforçavam a dependência da Marinha Mercante nacional dos grandes estaleiros do exterior.

Boa parte dos entraves materiais que impediam a implantação da indústria da construção naval pesada já tinha sido removida, principalmente com a entrada em operação da Companhia Siderúrgica Nacional (CSN, 1946), da Acesita (1951) e do Banco Nacional de Desenvolvimento Econômico (BNDE, 1952). Faltavam-nos políticas mais específicas voltadas para o setor, o que ocorreu apenas na formulação e na execução do Plano de Metas.

A construção naval constituiu-se num importante segmento da indústria pesada de transportes, com forte integração produtiva com as grandes siderúrgicas e o complexo eletro-metal-mecânico. Ao seu redor, formam-se as navipeças, isto é, aglomerado de indústria que fornece peças, equipamentos, insumos e presta serviços para os diversos segmentos que abrangem toda a indústria da construção 
naval. Os estaleiros formam o núcleo central desse aglomerado de indústria, onde eram construídas as embarcações e as grandes estruturas para segmentos marítimos. Destaca-se também a sua extensividade na contratação de trabalhadores, tanto direta como indireta (Araújo Júnior, 1985).

Podemos dividir o setor em dois grandes ramos: produtos para navegação e navios. O primeiro inclui armamentos e off-shore (plataformas de petróleo e gás natural); o segundo, as navipeças, os reparos navais e a conversão. As embarcações classificam-se em três tipos: barcos de lazer, navios de guerra e navios mercantes. Para a Marinha Mercante, são produzidas embarcações para navegação interior e de apoio. Quanto às oceânicas, podemos dividi-las em: cruzeiros, granéis (líquido e sólido) e de carga geral (cargueiro, porta-contêiner, rol-rol e frigorífico) (Grassi, 1995). Também há diferença entre a indústria da construção naval e a pesada naval; a primeira havia no Brasil, desde o século XIX; a segunda instalou-se somente após 1959.

Dada a dimensão dessa indústria, por um lado, ela só pode ser instalada num país que já tenha internalizado um sistema industrial completo e integrado com a presença de grandes oligopólios nacionais. Por outro, depende de políticas governamentais ativas, tanto para proteger o mercado como para financiar as grandes encomendas. Ter ampla frota mercante não significa que o país desenvolva também uma indústria naval pesada, como é o caso da Grécia, da Noruega e dos Estados Unidos. A formação e a constituição de ampla indústria da construção naval pesada são um imperativo político. E foi justamente essa opção que fez do Brasil um dos principais construtores navais do mundo, num curto intervalo de vinte anos, entre 1960 e 1980.

Até 1959, a indústria naval brasileira era pequena e fragmentada, tinha capacidade para atender encomendas de baixo volume (Brando, 1958). A partir de uma decisão política, foram selecionados estaleiros nacionais, atraídos novos do exterior e implementadas mudanças políticas e financeiras que permitiram desenvolver no país uma pesada indústria naval. O Estado criou e selou um forte elo inter-relacionado difusor de inovação entre a construção naval e a Marinha Mercante, associado ao movimento portuário.

Essa situação começou a se reverter no início da década dos anos 80, com o esgotamento de um padrão de industrialização e financiamento. A indústria naval foi duramente atingida, e os mecanismos de proteção e privilégios financeiros e políticos, rapidamente subtraídos, tanto da Marinha Mercante como da construção naval. Como resultado, houve desmonte parcial de ambos os setores, com alta capacidade ociosa e desnacionalização.

Rosenberg (2006, p. 97), discutindo a interdependência tecnológica, argumenta que "as invenções nunca emergem isoladamente". No processo de inovação e expansão produtiva, é mais comum a presença de "aglomerados de inovações inter-relacionados" (p. 101). A complementaridade entre as empresas que fazem parte desse "aglomerado" propicia a formação de um conjunto de inovações numa perspectiva sistêmica. O crescimento e o fortalecimento de empresas do mesmo ramo dinamizam e estimulam um processo de concorrência e de imitação, que, por sua vez, amplia a sua esfera de abrangência para outros ramos. Segundo Rosenberg (p. 125), "esse fluxo intersetorial da tecnologia constitui uma das mais inconfundíveis características das sociedades industriais avançadas”.

Ao longo do século XIX e durante as primeiras décadas do XX, na indústria da construção naval localizada no Rio de Janeiro, houve constante fluxo intersetorial do Arsenal da Marinha do Rio de Janeiro, dos estaleiros navais, das fundições (pequenas siderurgias) e do comércio exportador e importador, que possibilitou a manutenção e a ampliação do aglomerado de estaleiros navais. $\mathrm{O}$ ambiente propício ao desenvolvimento de aglomerados também es- 
tava associado ao bom desempenho da Marinha Mercante nacional, que atuava no transporte de cabotagem, uma vez que o Brasil tem um extenso litoral, com portos localizados nas principais cidades costeiras.

Nesse cenário, podemos afirmar que, com estaleiros localizados no Rio de Janeiro e em Niterói, se desenvolveu um sistema de inovação na indústria da construção naval. Segundo Nelson (2006), a inovação também se caracteriza pelo lançamento de um produto ou de um processo que seja novo para a empresa ou para o país, mas não significa que seja novo em termos mundiais, já que um sistema está relacionado a um conjunto de instituições que interagem com as empresas nacionais e determinam a performance inovadora.

Foi essa performance inovadora constante, ora mais intensa, ora mais lenta, ultrapassando as fronteiras setoriais e locais, que criou condições materiais para formar no país um sólido parque industrial naval, liderado por grandes empresas, interagindo com outros setores industriais, políticas públicas, instituições de pesquisas e sistema de crédito.

O surgimento de uma ou de várias indústrias numa determinada região altera o clima de uma época e cria uma expectativa favorável ao crescimento industrial. Segundo Perroux (1967), o fortalecimento de um grande ramo industrial vai favorecer o surgimento de atividades paralelas à “indústria-chave", cuja função é impulsionar um volume de produção global maior que o seu. Esse impulso forma um "polo de desenvolvimento", constituído por várias unidades fabris, ligadas entre si. A atividade de destaque serve como força motriz que exerce "efeitos de expansão" sobre outras unidades que com ela estão relacionadas. A unidade motriz gera "efeitos de aglomeração", reunindo atividades complementares no conjunto que trará vantagens cumulativas. A utilização de meios de transporte e de comunicação cria, entre as empresas, "efeitos de junção", aumentando cumulativamente a oferta e a procura, alargando o campo de possibilidades dos produtores locais. Os efeitos de aglomeração e de junção provocam o aparecimento de novas atividades, alterando a paisagem industrial regional e nacional (Ibidem).

A atuação do Estado no processo de formação da indústria da construção naval brasileira seguiu a mesma trajetória da sua atuação na constituição do sistema nacional de economia pautado na industrialização. De formas de intervenções mais indiretas, por meio de garantias de juros (ferrovias), subvenções (navegação) e proteção do mercado (Tarifa Alves Branco, cabotagem nacional, desvalorização cambial), até na década dos anos 30, a ações mais diretas atuando como Estado financiador, empresário e regulador, sobretudo no âmbito dos grandes planos nacionais entre 1940 e 1980.

$\mathrm{Na}$ ausência do capital financeiro, na perspectiva de $\mathrm{Ru}$ dolf Hiferding, em que o capital bancário privado se funde com a grande indústria, o Estado brasileiro viu-se na obrigação de preencher tal lacuna por meio da criação do Banco Nacional de Desenvolvimento Econômico (BNDE), criado em 1952. O BNDE tornou-se a principal alavanca para impulsionar grandes projetos industriais privados e estatais; também se destaca a criação de vários fundos de financiamentos para setores específicos da economia. Como Estado empresário, foram criadas grandes siderurgias, com destaque para a Companhia Siderúrgica Nacional, inaugurada em 1946; formado um sistema nacional de geração e transmissão de energia, fundida na grande holding estatal Eletrobras; prospectando e refinando petróleo com a Petrobras, de 1952; no setor de transporte, o Estado passou a ampliar suas funções com a criação da Rede Ferroviária Federal Sociedade Anônima (RFFSA), além de investir massiçamente no modal rodoviário por meio do Departamento Nacional de Estrada e Rodagem (DNER); na área de telefonia, o Estado encampou os fragmentados serviços regionais e formou um sistema nacional de telecomunicações. 
Com o Estado regulador, ampliou-se o protecionismo, manteve-se uma política cambial favorável e criaram-se inúmeros subsídios à agricultura. $\mathrm{Na}$ área de ciência $\mathrm{e}$ tecnologia, criaram-se o Conselho Nacional de Desenvolvimento Científico e Tecnológico (CNPq), a Coordenação de Aperfeiçoamento de Pessoal de Nível Superior (CAPES), além de ampliar o número de universidades federais (Draibe, 1985; Lessa, 1982; Tavares, 1998).

No longo período de industrialização (1930-1980), o Estado viu-se na obrigação de alargar suas funções porque havia uma inércia empresarial, cujo baixo grau de acumulação de capital nacional o impedia de dar saltos quantitativos e qualitativos, e porque as demandas sociais, seja dos trabalhadores, seja dos capitalistas, cresciam de forma exponencial e tencionava o Estado no sentido de atender aos reclames da sociedade e do capital (Lessa, 1982). Portanto, na construção naval e na Marinha Mercante, o Estado atuou como financiador, por meio do Fundo Nacional da Marinha Mercante (FNM), administrado pelo BNDE; como empresário, fazendo grandes aquisições para companhias estatais de navegação; e como regulador, por meio das agências, departamentos e superintendências, que executavam projetos, aproximava os armadores aos estaleiros e definia normas no sistema de fretes (Barat, 1996).

Neste artigo, discutiremos essa trajetória, a formação e a dissolução desse elo estabelecido pelas políticas de Estado. Além desta introdução, o artigo está estruturado em três tópicos: inicialmente, será apresentada a formação do novo aparato político, administrativo e financeiro, como condição necessária para montar a indústria naval pesada de 1959 a 1969. O momento seguinte abrangerá a fase da SUNAMAM e a execução dos Planos I e II da Construção Naval, entre 1971 e 1980, e a tentativa de seguir com planos permanentes em 1981 e 1982. No terceiro tópico, discutiremos o período entre 1983 e 1989, que compreende o início e a consolidação do agravamento da situação da SUNAMAM como fruto da crise econômica e da imobilidade estatal para executar novos planos de desenvolvimento.

\section{2_Construção naval pesada 1959-1969: do FMM à criação da SUNAMAM}

Se no século XIX havia um pequeno aglomerado de estaleiros no Rio de Janeiro, liderado pelo AMRJ, a falta da indústria de base e as encomendas feitas no exterior pelas companhias de navegação estatais e privadas quase desmontaram esse aglomerado, quando a indústria naval passou a ser pautada pelo aço e pela mecânica elétrica. Para os estaleiros nacionais, ficaram reservados apenas os reparos e a construção de pequenas embarcaçoes, o que tinha uma demanda muito irregular (Goularti Filho, 2009a).

Na primeira metade dos anos 1950, a indústria naval brasileira apresentava características de um setor sem articulação comercial e produtiva. A performance inovadora desse aglomerado estava comprometida pela falta de uma política industrial e de grandes encomendas. As atividades comerciais e industriais inter-relacionadas com a indústria naval, aos poucos, foram redirecionando suas estratégias, reduzindo a integração produtiva e comercial com os estaleiros. Com isso, criava-se um ciclo vicioso que aprofundava ainda mais as dificuldades de expansão da indústria da construção naval.

Segundo um levantamento feito pelo Ministério de Viação e Obras Públicas (1958), quando da elaboração do Plano de Metas, havia no Brasil 13 estaleiros, dos quais quatro estavam instalados na Baia da Guanabara e os demais distribuídos nas seguintes cidades: Santos, Salvador, Rio Grande, Porto Alegre, Vitória, Recife e Belém, além de outros dois no Rio Paraná e no Rio Paraguai. Os localizados na Baía da Guanabara eram: Estaleiro Ilha Viana da 
Navegação Costeira, que fazia basicamente reparos para a frota estatal; Estaleiro Mauá, que atendia às demandas da Companhia Comércio e Navegação; Estaleiro do Lloyd Brasileiro, que fazia os reparos para a própria empresa; e o Estaleiro Caneco, o maior de todos, que diversificava mais sua carteira de clientes. Os demais estaleiros espalhados pelo litoral, inclusive os dois no interior, atendiam apenas às demandas locais na construção de pequenas embarcações e aos reparos das companhias locais e eventualmente prestavam serviços às grandes companhias.

Durante o governo de Juscelino Kubitschek (1956-1960), podemos destacar três medidas institucionais que alteraram a forma e a magnitude do aglomerado da indústria da construção naval no Rio de Janeiro e, por extensão, no Brasil: a inclusão da Meta 11 - Marinha Mercante - e da Meta 28 - Construção Naval - no Plano de Metas; a criação do Grupo Executivo da Indústria da Construção Naval (Geicon); e a aprovação do Fundo da Marinha Mercante (FMM) e da Taxa de Renovação da Marinha Mercante (TRMM).

O Plano de Metas, por meio da Meta n. 11, direcionou parte das novas encomendas para a renovação da frota mercante nacional (privada e estatal) ao mercado interno. Petrobras, Vale do Rio Doce, CSN e Lloyd Brasileiro se comprometeriam a comprar embarcações no país, como condição necessária para a expansão da "nova" indústria da construção naval. A Meta 28 avaliava que já haviam sido implantadas no Brasil as bases necessárias para a constituição de um novo aglomerado de estaleiros, faltando apenas criar os mecanismos de financiamento e orientar as novas encomendas para o mercado interno. Portanto, as Metas 11 e 28 estavam indissociáveis (Conselho de Desenvolvimento, 1958).

Segundo Lessa (1982,p. 27), como um todo, o Plano de Metas se constituiu num projeto ousado, que visava implantar as bases do processo industrial brasileiro, configurando-se na "mais sólida decisão consciente em prol da industrializa- ção na história econômica do país". Foi intencionalmente elaborado com objetivo claro: implantar a indústria de bens de produção. O Plano de Metas "conferia prioridade absoluta à construção dos estágios superiores da pirâmide industrial verticalmente integrada e do capital social básico de apoio a esta estrutura" (Ibidem). A participação estatal se explicava pelo crescente aumento das demandas sociais, pela inércia empresarial e pela incapacidade do setor privado de fazer certos investimentos que demandavam recursos vultosos.

As principais metas para a construção naval eram as seguintes:

a) a criação de capacidade de construção de embarcações suficiente para atender à demanda prevista para reposição da frota de cabotagem e seu incremento e o aumento da participação da bandeira brasileira nos transportes de longo curso;

b) o aumento da capacidade de reparos, principalmente de grandes reparos, e a melhor distribuição entre os vários portos do país de modo a tornar a manutenção e a conservação da frota nacional independente dos estaleiros estrangeiros;

c) o aumento da capacidade de docagem e sua melhor distribuição entre os portos nacionais, de modo a dispensar a frota nacional da docagem em portos estrangeiros e proporcionar-lhes melhor assistência em seu regime de operação (Conselho de Desenvolvimento, 1958, p. 348).

Para cumprir essas metas, foram apresentados quatro grandes projetos: o reaparelhamento da Ilha Viana, ampliando sua capacidade de reparo para grandes embarcações; a construção de mais dois estaleiros de grande porte com capital externo, que seriam responsáveis por dar um impulso modernizante aos estaleiros nacionais; o reapare- 
Tabela 1_Plano de Metas - Meta 28: Construção Naval (em mil TPB)

\begin{tabular}{|c|c|c|c|c|c|}
\hline Aumento da capacidade & 1958 & 1959 & 1960 & 1961 & 1962 \\
\hline No estaleiro oficial da llha Viana & - & - & 10 & 10 & 10 \\
\hline Nos dois novos estaleiros particulares de 50.000 TPB cada um & - & 5 & 15 & 60 & 100 \\
\hline Nos estaleiros pequenos destinados ao reaparelhamento da frota privada & 5 & 10 & 20 & 20 & 20 \\
\hline Total & 5 & 15 & 45 & 90 & 130 \\
\hline
\end{tabular}

Fonte: Ministério da Viação e Obras Públicas, 1958.

lhamento dos pequenos estaleiros nacionais selecionados; e a construção de três grandes diques, localizados no Rio de Janeiro, em Santos e no Rio Grande. Em 1958, a capacidade de produção era de 5.000 TPB (Toneladas de Porte Bruto) anuais, e o objetivo era ampliar para 130.000 TPB em 1962, entre os quais $100.000 \mathrm{TPB}$ estariam sob a responsabilidade dos dois novos estaleiros advindos do exterior, 20.000 TPB, dos nacionais reaparelhados, e 10.000 TPB, da Ilha Viana. A parte reservada aos nacionais parecia pequena, mas significava dobrar a sua capacidade instalada em quatro anos.

O decreto que criou a Comissão da Marinha Mercante (CMM), em 1941, centralizou suas funções na normatização das tabelas de tráfegos, na definição das linhas, nas subvenções e na autorização para importar materiais, sem fazer referência à construção naval. Somente mediante orçamento aprovado pela Presidência da República era possível a CMM financiar a aquisição, a construção e os reparos do material flutuante da frota nacional, ou seja, a CMM tinha função mais normativa do que executiva. Essa situação se reverteu com a criação do Geicon, em 1958, por meio do Decreto n. 43.899, de 13 de junho, cujas duas atribuições seriam:

a) estudar, propor e estabelecer as normas e critérios gerais a serem observados pelos diversos órgãos governamentais, para execução das metas da Construção Naval; e

b) estudar, coordenar, aprovar e propor as medidas necessárias à realização dos projetos de estaleiros de Construção Naval, previstos nas metas estabelecidas pelo Governo (Decreto n ${ }^{\circ} 43.899$, de 13 de junho de 1958).

Entre os membros que faziam parte do Grupo estava o presidente da CMM, além de diversos representantes do executivo e de bancos federais. $O$ Geicon atuou ativamente durante a execução do Plano de Metas, aprovando os projetos de instalação de outros estaleiros e a ampliação dos existentes, autorizando a concessão de crédito e definindo as metas de nacionalização das novas embarcações construídas no território nacional.

Uma batalha encampada pelo Geicon foi a formulação da proposta para criação do FMM e do TRMM. Após amplo debate no Congresso, ambos foram criados por meio da Lei n. 3.381, de 24 de abril de 1959, com a finalidade de prover recursos para a renovação e a recuperação da Marinha Mercante e a formação de um parque industrial naval no país. Os recursos do FMM seriam obtidos por meio das principais fontes seguintes:

a) do produto da Taxa de Renovação da Marinha Mercante (TRMM) arrecadada pelas empresas navegação estrangeiras, pelas de propriedade da União e também pelos armadores nacionais que operem navios estrangeiros afretados;

b) de $32 \%$ da receita da taxa de despacho aduaneiro; 
c) dos juros, comissões e outras receitas resultantes da aplicação dos recursos do próprio Fundo ou a execução desta lei;

d) das dotações orçamentárias que lhe forem atribuídas no Orçamento Geral da União (Lei n. 3.381, de 24 de abril de 1959).

Os recursos arrecadados seriam recolhidos ao Banco Nacional de Desenvolvimento Econômico (BNDE), numa conta especial, à ordem da CMM, e deveriam ser destinados à renovação da frota mercante nacional e ao financiamento de empresas de reparos e de construção naval para melhorar e ampliar suas instalações. Estavam criadas as condições institucionais e financeiras para formar no país um novo aglomerado inter-relacionado de estaleiros com alta capacidade de inovação. Nascia no Brasil a indústria da construção naval pesada.

Para cumprir as metas de construção, elevadas para $160.000 \mathrm{TPB}$, foram selecionados quatro estaleiros nacionais (dois médios e dois pequenos) e implantados dois estrangeiros, que passaram atuar como indústrias motrizes do aglomerado. Os nacionais foram o Estaleiro Mauá e as Indústrias Reunidas Caneco, ambos de porte mediano, e o Estaleiro Só e o Estaleiro Emaq - Engenharia e Máquinas S.A., de pequeno porte. Contudo, o maior investimento realizado no aglomerado foi a implantação do Ishikawajima do Brasil Estaleiro S.A. (Ishibrás), de origem japonesa, e o Verolme Estaleiros Reunidos do Brasil S.A., de capital holandês.

Logo após a aprovação do FMM e da TRMM, o Geicon, coordenado pela CMM, tratou de fazer as primeiras encomendas para os estaleiros selecionados, com o intuito de renovar a frota estatal. No Ishibrás, foram encomendados cinco navios, de 5.600 TPB; no Verolme, dois, de 10.500 TPB; no Mauá, quatro, de 1.550 TPB, e dois, de 6.175 TPB, no Emaq, dois, de 2.200 TPB; no Caneco, um, de 2.200 TPB; e no Só, um, de 2.200 TPB. As primeiras encomendas já demonstravam a diferença da capacidade instalada, existente nos estaleiros nacionais e nos estrangeiros (Comissão da Marinha Mercante, 1961).

Em 1962, com o aglomerado da indústria naval implantado e um índice de nacionalização em preço de $81 \%$, encerraram-se as importações de navios novos e de segunda mão. Para os próximos anos, todas as encomendas deveriam ser atendidas pela indústria doméstica. No governo de João Goulart, que tinha como objetivo reforçar o caráter nacional da economia, foi elaborado o "Programa de Construção Naval 1963-1965”, dentro do Plano Trienal de Desenvolvimento Econômico e Social. Esse programa previa a construção de 40 embarcações, num total de 545.700 TPB, além de duas destinadas ao mercado externo, de 14.000 TPB cada uma (Comissão da Marinha Mercante, 1963).

Tabela 2_Programa de Construção Naval 1963-1965

\begin{tabular}{l|r|r} 
Empresas & Navios & \multicolumn{2}{c}{ Tonelagem TPB } \\
\hline Lloyd Brasileiro & 12 & 115.500 \\
\hline Navegação costeira & 6 & 33.600 \\
\hline Fronape - Petrobras & 4 & 213.000 \\
\hline $\begin{array}{l}\text { Docenave - Vale do Rio Doce } \\
\text { (atual Vale) }\end{array}$ & 2 & 90.000 \\
\hline Companhia Siderúrgica Nacional & 1 & 14.000 \\
\hline SNAPP & 2 & 4.400 \\
\hline Armadores privados & 11 & 61.200 \\
\hline Exportação & 2 & 14.000 \\
\hline Total . . . . . . . . . . . . . . . . . . . & 545.700
\end{tabular}

Fonte: Comissão da Marinha Mercante, 1963.

A frota nacional de petroleiros, pertencente à Petrobras, e à Docenave, da então Vale do Rio Doce, hoje Vale, 
eram as duas principais âncoras do programa, concentrando $57,0 \%$ das encomendas domésticas. Os armadores privados, mesmo encomendando 11 embarcações, representavam apenas $11,5 \%$. A novidade estava nas duas encomendas externas, destinadas ao México, o que colocava o Brasil entre o rol dos exportadores de navios.

Os resultados para o aglomerado, após 1963, não foram os esperados, uma vez que a economia brasileira, que vinha de uma fase expansiva desde 1956, em torno de 8,5\% ao ano, iniciou uma trajetória de desaceleração. Entre $1963 \mathrm{e}$ 1966, a taxa de crescimento do PIB brasileiro caiu para 2,8\%, repercutindo diretamente na recém-instalada indústria da construção naval pesada, que reduziu o ritmo das operações. Destaca-se também, nesse período, a instabilidade política que culminou com o golpe militar em março de 1964, fazendo cessar a construção democrática que o país vinha ensaiando desde 1946 e instalando uma áspera ditadura militar.

Os militares no poder deram um novo rumo à Marinha Mercante e à construção naval, fortalecendo seu caráter privado e nacional com a transformação do Lloyd Brasileiro e do Estaleiro da Ilha Viana em economia mista de capital aberto, desonerando o Tesouro Nacional de financiar seus sucessivos déficits (Goularti Filho, 2009b). Outra mudança significativa foi a transformação da CMM em Superintendência Nacional da Marinha Mercante (SUNAMAM), por meio do Decreto n. 64.125, de 19 de fevereiro de 1969, que não alterou apenas o nome da CMM, mas significou a centralização e o fortalecimento das políticas voltadas para a Marinha Mercante e a construção naval, sob o novo comando da SUNAMAM. Com base em três novos decretos (Decreto-Lei n. 11.143/1970, Decreto n. 67.992/1970 e Decreto n. 73.838/1974), a SUNAMAM passou a ter o controle quase que absoluto da navegação marítima e fluvial, envolvendo os fretes, as empresas de navegação, a elaboração de planos para a construção naval e a liberação de recursos.
Esse poder atribuído à SUNAMAM estava garantido pelos vultosos recursos que ela gerenciava no FMM. $\mathrm{O}$ fortalecimento da SUNAMAM inaugurou uma fase especial para o setor naval e a navegação, pautada em três ações: proteção à navegação nacional, apoio aos armadores nacionais e estímulo à indústria da construção naval. Concretamente estava consolidada a indissociabilidade entre a Marinha Mercante e a construção naval, com claros objetivos de expandir e fortalecer a economia nacional.

No final dos anos 1960, além da CSN e da Acesita, já estavam em operação na produção de aço e perfilados a Cosipa e a Usiminas, duas grandes siderúrgicas estatais, aptas a atender às demandas da indústria pesada de transportes (Sindicato da Indústria da Construção Naval do Rio de Janeiro, 1962).

Com relação aos armadores privados nacionais, contando com a navegação interior, em 1956 havia no país 119, “a maior parte deles empresas de pouca expressão (Comissão da Marinha Mercante, 1957, p. 6). A maior companhia privada continuava sendo a Comércio e Navegação, com uma frota de 18 navios. As grandes bacias hidrográficas estavam reunidas em três áreas, sendo exploradas principalmente pelas autarquias federais: Serviço de Navegação da Amazônia e de Administração do Porto do Pará (SNAPP), criada em 1940, a partir da encampação da The Amazon Steam Navigation Co.; Serviço de Navegação da Bacia do Prata (SNBP), criado em 1943; e Companhia de Navegação do São Francisco (CNSF), fundada em 1955.

No transporte de longo curso, atuavam apenas: o Lloyd Brasileiro (com 24 navios); a Frota Nacional de Petróleo (Fronape), criada em 1949, com 25 navios, e incorporada pela Petrobras em 1952; a Companhia Siderúrgica Nacional (CSN), com dois navios. As três eram responsáveis por apenas 3,9\% das exportações e por 10,5\% das importações. A cabotagem de longa distância era quase um serviço exclusivo 
do Estado. Além do Lloyd Brasileiro e da Navegação Costeira, a Fronape e a CSN também atuavam no transporte de matéria-prima. Em toneladas por milhas transportadas, $50 \%$ eram da responsabilidade de empresas estatais (Comissão da Marinha Mercante, 1957).

No tocante ao estímulo às companhias nacionais, a reestruturação do Lloyd Brasileiro transformou-as em sociedades anônimas. A dissolução da Navegação Costeira, em 1966, abriu espaço para as companhias privadas de navegação. Na época, a intenção da CMM já era formar grandes companhias, ao invés de pulverizar o setor em pequenas e médias empresas. No início dos anos 60, já havia seis companhias privadas que atuavam no longo curso, tendo apenas oito navios, com capacidade para 35.810 toneladas (Comissão da Marinha Mercante, 1961). Destacavam-se duas empresas, a Companhia de Navegação Netumar e a Empresa de Navegação Aliança. Dentro da CMM, financiada pelo BNDE, foi criada a Companhia Libra de Navegação em 1966, a partir da fusão de 13 pequenas companhias que faziam o transporte de cabotagem. Outras empresas que também atuavam no longo curso eram: a Companhia Paulista de Comércio Marítimo, a Frota Oceânica Brasileira, a Empresa de Navegação Mercantil (antiga Comércio e Navegação), a L. Figueiredo Navegação e a Netúnia Sociedade de Navegação (Superintendência Nacional da Marinha Mercante, 1969-1972).

\section{3_Recuperação e expansão: a SUNAMAM e os planos estruturantes 1969-1982}

A política econômica dos primeiros anos da ditadura militar cristalizou-se no Plano de Ação Econômica do Governo 1966-1968 (PAEG), que tinha como principal objetivo a eliminação dos gargalos econômicos que impediam a retomada do crescimento. De imediato, implementou-se uma reforma bancária, criando-se o Banco Central do Brasil e o Conselho
Monetário Nacional. Em seguida, foram adotadas medidas fiscais para ampliar as receitas por meio da concentração de tributos na esfera federal. Para resolver o problema das contas públicas, foram lançados títulos indexados na Obrigações Reajustáveis do Tesouro Nacional (ORTN), associados à recém-criada correção monetária. No que tange ao lado externo da economia, foram estabelecidas medidas institucionais que regulamentaram a Lei de Remessa de Lucros ao Exterior e liberaram a importação de vários itens, que facilitaram a captação de recursos no exterior pelas empresas de capital externo (Belluzzo \& Cardoso de Mello, 1984). Os principais resultados do PAEG foram: a) o Estado restabeleceu a capacidade de financiamento; b) os canais de financiamentos externos foram abertos; c) formou-se uma demanda diferenciada, composta de segmentos da classe média. No conjunto, criou-se uma expectativa favorável de retomada do crescimento com estabilidade de preços, finanças sadias e controle sindical, fato que se consumou, nos anos seguintes, no "milagre econômico".

Tabela 3_Capacidade instalada e produção efetiva dos estaleiros brasileiros 1959 e 1966

\begin{tabular}{|c|c|c|c|}
\hline Estaleiros & Localização & $\begin{array}{l}\text { TPB } 1959 \\
\text { (aprovado } \\
\text { pelo Geicon) }\end{array}$ & $\begin{array}{l}\text { TPB } 1966 \\
\text { (produção } \\
\text { efetiva) }\end{array}$ \\
\hline Ishibrás & Rio de Janeiro & 60.000 & 28.222 \\
\hline EMAQ & Rio de Janeiro & 8.000 & 5.400 \\
\hline Caneco & Rio de Janeiro & 2.000 & 3.948 \\
\hline Mauá & Niterói & 25.000 & 36.358 \\
\hline Verolme & Angra dos Reis & 40.000 & 26.771 \\
\hline Só & Porto Alegre & 5.000 & 3.026 \\
\hline
\end{tabular}

Fonte: Comissão da Marinha Mercante, 1967.

Nesse ambiente de incerteza, entre 1964 e 1966, a indústria naval sentiu os efeitos da desaceleração econômica e 
utilizava apenas 60,0\% da sua capacidade instalada (Tabela 3). Das encomendas realizadas em 1963, dentro do Programa de Construção Naval, dada a instabilidade política e econômica, algumas não foram efetivadas, e outras, entregues no prazo. Não havia novas encomendas previstas. Para evitar desmantelamento no aglomerado, já fortemente integrado com as indústrias siderúrgica, elétrica e metal-mecânica, em 1967 a CMM lançou o Plano de Emergência da Construção Naval - 1968/1970, financiando a construção de 74 embarcações, num total de 365.570 TPB, além de outras 14 de pequeno porte para navegação fluvial. Previa-se, porém, que as encomendas dos cargueiros de longo curso seguiriam, após 1970, em torno de 180.000 TPB, acumulando em todo o Plano 545.570 TPB (Superintendência Nacional da Marinha Mercante, 1969-1970).

Tabela 4_Encomendas previstas no Plano de Emergência da Construção Naval - 1968/1970 (em TPB)

\begin{tabular}{|c|c|c|c|}
\hline Encomendas & 1968 & 1969 & 1970 \\
\hline 32 cargueiros de longo curso & 57.350 & 44.600 & 72.000 \\
\hline $\begin{array}{l}5 \text { graneleiros de longo curso } \\
\text { para sólidos }\end{array}$ & 54.300 & 46.000 & \\
\hline 24 cargueiros de cabotagem & 38.720 & 23.400 & 20.200 \\
\hline $\begin{array}{l}2 \text { graneleiros de cabotagem } \\
\text { para líquidos }\end{array}$ & 2.500 & 2.500 & \\
\hline $\begin{array}{l}11 \text { graneleiros de } \\
\text { navegação interior }\end{array}$ & 4.000 & & \\
\hline Total & 156.870 & 116.500 & 92.200 \\
\hline
\end{tabular}

Fonte: Ministério dos Transportes, 1968.

Das encomendas, estavam destinados $54,5 \%$ a dois estaleiros estrangeiros, e o restante, para os nacionais, concentrando-se 40,8\% no Caneco, no Mauá, no Emaq e no Só - que também passaram a atuar como indústrias motrizes -, e 4,7\% para outros estaleiros pequenos. Em boa medida, todas as encomendas foram entregues, 409.472 TPB até 1970, mostrando o êxito do plano, que, embalado pela retomada do crescimento da economia brasileira, criou novamente um clima de expectativas favoráveis para o aglomerado.

Nesse clima de euforia, foi lançado pela SUNAMAM, em 1970, o ousado I Plano da Construção Naval 1971-1975 (I PCN), que previa a construção de 2.235.040 TPB até o final do período. O I PCN estava em consonância com o I Plano Nacional de Desenvolvimento 1971-1974 (I PND), apresentado pelo presidente Médici, que previa aumento de $41,0 \%$ do PIB para o período.

A disponibilidade de crédito externo, a melhoria nas condições fiscais e financeiras do Estado e o planejamento criaram condições favoráveis para a retomada do crescimento da economia brasileira. A primeira metade dos anos 70 foi marcada pelo alto crescimento econômico e pela acentuada ampliação da infraestrutura de transportes e comunicações. Nesse contexto foi executado o I PCN.

Na Tabela 5, podemos ver que o processo de fortalecimento dos grandes estaleiros se expandiu com o I PCN. O Ishibrás e o Verolme, mesmo construindo 27 embarcações, do total de 278 , representavam $37,1 \%$ e $29,1 \%$, respectivamente, das encomendas em TPB. $\mathrm{O}$ maior estaleiro nacional era $\mathrm{o}$ Mauá, que representava 18,2\%. Os cargueiros, os petroleiros e os graneleiros ficavam sob a responsabilidade dos cinco maiores estaleiros, ao passo que as chatas, as barcaças, as lanchas e os rebocadores cabiam aos estaleiros menores.

A industrialização pesada brasileira, iniciada em 1956, que internalizou partes avançadas da Segunda Revolução Industrial, e a execução de políticas voltadas para a Marinha Mercante e a construção nacional permitiram a formação de um aglomerado inter-relacionado e difusor de inovação, voltado para os estaleiros. Liderado por grandes estaleiros, motrizes da integração e da inovação, o aglomerado poderia ser assim dividido: 
Tabela 5 Previsão do I Plano da Construção Naval 1971-1975

\begin{tabular}{l|r|r|r} 
Estaleiros & TPB & Embarcações & Participação (em \%) \\
\hline Ishibrás & 830.300 & 11 & 37,1 \\
\hline Verolme & 650.000 & 16 & 29,1 \\
\hline Mauá & 406.700 & 28 & 18,2 \\
\hline Emaq & 131.400 & 12 & 5,9 \\
\hline Só & 89.710 & 43 & 4,0 \\
\hline Caneco & 82.220 & 14 & 3,7 \\
\hline Outros & 44.510 & 154 & 2,0 \\
\hline Total & 2.234 .840 & 278 & 100,0 \\
\hline
\end{tabular}

Fonte: SUNAMAN, 1971; Geipot, 1999.

- Indústria pesada: aço, motores diesel, escotilhas mecânicas, mecânicos mastro e paus de carga,

- Indústria média: máquinas de leme, guinchos, molinetes, cabrestantes, bombas em geral, compressores, instalações frigoríficas e desumidificadoras, geradores elétricos, quadros, cabos e equipamentos elétricos, eixos hélices, fundidos e forjados.

- Indústria leve: receptores e transmissores de rádio, aparelhos eletrônicos, revestimentos, isolamentos, forração, mobiliário, aparelhos hidráulicos, canalizações, válvulas, maçame, poleame e ornamentação.

A presença desses equipamentos na indústria brasileira formou a chamada navipeças, parte integrante do aglomerado da indústria da construção naval pesada. A navipeças tem caráter nacional e surgiu exclusivamente para atender aos estaleiros e/ou a muitos empresários, que diversifica- ram suas empresas e também passaram a produzir ou a fornecer insumos navais.

Eram importados agulhas magnéticas e giroscópicas, pilotos automáticos, sistema de automação e controle remoto da propulsão, radares ecobatimentros, hodômetros e perfilados especiais de aço, ou seja, equipamentos de maior conteúdo tecnológico, ligados à indústria eletrônica e à microeletrônica, ainda inexistente no território nacional (Superintendência Nacional da Marinha Mercante, 1970-1974).

Na navegação de cabotagem, apesar da forte presença das empresas estatais, sempre houve a atuação das pequenas companhias regionais. Com a extinção da Navegação Costeira, em 1966, e o Lloyd Brasileiro dedicando-se apenas no longo curso, as companhias regionais ampliaram suas áreas de abrangência. Houve um processo de concentração e centralização de capital, apoiado pela SUNAMAM, que selecionou 13 companhias privadas para serem incluídas nos seus planos de expansão (Superintendência Nacional da Marinha Mercante, 1971).

Com relação à proteção da navegação nacional, foram estabelecidos acordos bilaterais e controle das conferências, além da reserva de carga e da vigilância sobre as operações das empresas do ramo. Essas medidas visavam ampliar a participação da bandeira nacional no tráfego de longo curso, que diretamente beneficiava a indústria da construção naval. Por exemplo, no tráfego geral de cargas que definiu o critério 40-40-20 (40\% do transporte de cargas por navios de bandeira brasileira, $40 \%$ por navios de bandeira do parceiro comercial do Brasil e $20 \%$ por navios da chamada $3^{a}$ bandeira) e fixou a participação mínima do país exportador e/ou importador, inicialmente de $65 \%$, até atingir $80 \%$. As cargas importadas destinadas às empresas estatais ou a órgãos governamentais, cobertas com algum benefício financeiro, somente poderiam ser transportadas 
por empresas nacionais de navegação (Empresa Brasileira de Planejamento de Transportes, 1999a).

A renovação da frota mercante nacional, que se expandia com a maior participação da bandeira brasileira no comércio de longa distância, garantia o ritmo acelerado de crescimento da indústria naval pesada. O sucesso do I PCN exigiu a continuação do planejamento e a ampliação das encomendas. O ano de 1974, porém, começou mostrando claras tendências de desaceleração das taxas de crescimento na economia brasileira. $\mathrm{O}$ aumento do fluxo financeiro especulativo mundial, associado ao primeiro choque do petróleo, desencadeou a maior crise econômica global pós-1945, que rebateu na economia doméstica. Para continuar com o mesmo ritmo de crescimento, manter expectativas, superar a crise e completar o parque industrial brasileiro, em meados de 1974 foi apresentado o II PND 1975-1978, que previa ampliar o PIB em 61,0\%. Especificamente para a construção naval, o plano supunha aumentar a capacidade instalada de 410.000 TPB para 1.140.000 TPB, representando aumento de $178,0 \%$ em apenas quatro anos.

Na esteira do II PND, foi lançado pela SUNAMAM o II PCN, que previa investimento na ordem de 3,3 bilhões de dólares, contratando 5.300.000 TPB, e concluir 1.300.00 TPB já contratados no plano anterior, também para atender aos mercados interno e externo. O objetivo era fazer do Brasil uma potência mundial na construção naval, ao lado do Japão e da Coreia do Sul, ampliando as exportações de manufaturados. Há que se destacar que a capacidade instalada nos estaleiros no Brasil estava aquém das encomendas previstas no II PCN.

Havia também as embarcações contratadas para o mercado externo, que chegavam a 1.350.629 ТРB. Comparando-se os dois planos, percebe-se aumento na participação dos estaleiros nacionais, destacando-se o Caneco, que passou de $3,7 \%$, no I PCN, para $15,7 \%$, no II PCN, ampliando sua ca-
Tabela 6_Previsão do II Plano da Construc̣ão Naval 1975-1980

\begin{tabular}{|c|c|c|c|}
\hline Estaleiros & TPB & Embarcações & Participação (em \%) \\
\hline Ishibrás & 1.382.200 & 15 & 30,0 \\
\hline Verolme & 1.230 .000 & 13 & 26,7 \\
\hline Mauá & 755.074 & 42 & 16,4 \\
\hline Emaq & 419.306 & 14 & 9,1 \\
\hline Caneco & 723.390 & 27 & 15,7 \\
\hline Outros & 94.440 & 79 & 2,1 \\
\hline Total & 4.604 .410 & 190 & 100,0 \\
\hline
\end{tabular}

Fonte: SUNAMAN, 1975; Geipot, 1999

pacidade motriz e difusora de inovação. Para o mercado externo, havia equilíbrio entre os quatro grandes estaleiros, sendo que cada um ficou responsável por atender em torno de $21,0 \%$ das encomendas em TPB.

A trajetória de crescimento virtuoso no país, porém, começou a se reverter com o esgotamento dos padrões de financiamento, calcada no capital externo, nas finanças públicas e no autoritarismo político. Iniciamos uma nova trajetória, baseada no aprofundamento do endividamento externo que rebatia internamente, desestabilizando a situação fiscal e financeira no Estado (Carneiro, 2002). Essa instabilidade começava a engessar o Estado, que não conseguia mais cumprir suas metas, plasmadas no II PND, que rebatia na Marinha Mercante e na construção naval.

Com a desaceleração da economia brasileira e as dificuldades na liberação de recursos financeiros, as encomendas atrasaram, e os estaleiros que se tinham preparado para o II PCN começaram a operar com capacidade ociosa. O estaleiro Caneco entregou suas encomendas de 1974 apenas em 1985, o Mauá, em 1988, e o Emaq, em 1986. O Ishibrás e o Verolme cumpriram parcialmente os contratos, concluindo suas obras entre $1982 \mathrm{e} 1983$. As encomendas menores feitas 
Tabela 7_Contratações realizadas pelos PPCNs 1981 e 1982 nos principais estaleiros

\begin{tabular}{|c|c|c|c|c|c|}
\hline \multirow{2}{*}{ Estaleiro } & \multicolumn{2}{|l|}{ I PPCN 1981} & \multicolumn{2}{|l|}{ II PPCN 1982} & \multirow{2}{*}{ Participação (em \%) } \\
\hline & TPB & Embarcações & TPB & Embarcações & \\
\hline Caneco & 109.000 & 5 & & & 10,0 \\
\hline Mauá & 256.760 & 7 & 13.800 & 4 & 24,7 \\
\hline Ishibrás & 376.060 & 5 & 24.700 & 1 & 36,6 \\
\hline Verolme & 225.000 & 3 & 89.000 & 2 & 28,7 \\
\hline Total & 966.820 & 20 & 127.500 & 7 & 100,0 \\
\hline
\end{tabular}

Fonte: SUNAMAM, 1981-1982.

ao estaleiro Ebin foram todas entregues no prazo (Empresa Brasileira de Planejamento de Transportes, 1999a).

Após três décadas de considerável crescimento econômico (em média de $7 \%$ ao ano), financiado com recursos externos e públicos, os anos 80 começam dando claros sinais de esgotamento desse padrão de financiamento. Com dois anos de atraso, foi lançado pelo presidente João Figueiredo o III PND 1980-1985, que centrava suas ações na estabilidade econômica (fiscal e de preços) e na ampliação das exportações para reduzir as vulnerabilidades externas e substituir derivados de petróleo. Ao contrário dos planos anteriores, o III PND não estabelecia metas de crescimento, nem definia as fontes financiadoras e o destino dos recursos. $\mathrm{Na}$ verdade, o plano incorporava o espírito da época, que iniciava com o controle dos gastos e as tentativas fracassadas de estabilizar os preços. Como resultado, revertemos uma trajetória de crescimento e assistimos à maior recessão da história do país, com queda média de 2,3\% do PIB, entre 1981 e 1983. Esse cenário rebateu em vários segmentos da economia brasileira, em especial na indústria pesada, cujas encomendas encolheram de forma acentuada (Tavares \& Belluzzo, 1984).

A SUNAMAM teve de se ajustar à nova realidade para cumprir as metas estabelecidas ainda no II PCN, que se encerrava em 1981, e resolveu estender suas encomendas para os anos seguintes, além de projetar outras. Para tanto, abandonou a ideia de planos mais longos e ousados e decidiu atender às demandas mais urgentes, projetando-as de forma anual e "permanente". Foram formulados os Planos Permanentes da Construção Naval (PPCN) de 1981 e 1982. O PPCN de 1981 ainda guardava algumas proporções dos anteriores, prevendo a construção para aquele ano de 966.820 TPB. Em compensação, o PPCN de 1982, o último formulado pela SUNAMAM, ajustou-se à realidade e contratou apenas $131.783 \mathrm{TPB}$, incluindo todos os estaleiros. A saída para o setor seria apostar nas exportações, que também eram um dos objetivos do governo federal. Por meio de financiamento proveniente da Carteira de Comércio Exterior do Banco do Brasil (Cacex), foram encomendadas, para o período 1981-1983, 13 grandes embarcações, totalizando 1.264.820 TPB, número superior à demanda interna.

Os resultados dos PPCNs ficaram abaixo do esperado, quando foram entregues em 1983, contando com as encomendas da década passada, apenas 1.098.558 TPB, ou seja, apenas $50 \%$ do planejado. Diante desse quadro, instalou-se um clima de expectativas negativas no aglomerado naval e na navegação, que se foi ampliando ao longo da década, iniciada com queda acentuada no PIB de -4,4\% em 1981. 


\section{4_Crise e desmonte da SUNAMAM 1982-1989}

$\mathrm{Na}$ década de 1970, a frota mercante nacional ampliou-se consideravelmente, passando de 2.339.000 TPB, em 1970, para 8.069.000 TPB, em 1980, aumentando a participação dos navios com bandeira brasileira (exportações e importações) de $34,6 \%$ para $49,6 \%$, respectivamente, dobrando a atuação nacional na frota mundial de longo curso, de 0,5\% para 1,0\%. O emprego na indústria da construção naval passou de 18.000 trabalhadores, em 1970, para 33.792, em 1980, tornando-se a segunda potência mundial no setor, abaixo apenas do Japão (Anexos 1 e 2).

Dos armadores privados beneficiados pelos planos da SUNAMAM, podemos destacar: a Frota Oceânica, a Aliança, a Paulista, a Netumar, a Mercantil e a Libra. Outras empresas menores, ou que atuavam apenas na cabotagem, também passaram a participar do longo curso, como a Companhia de Navegação do Norte, a H. Dantas Comércio Navegação, a Companhia de Navegação Norsul, a Companhia de Navegação Viamar, a Transportes Marítimos Internacionais, a Interunion Navegações e a Companhia de Navegação Tupi (Empresa Brasileira de Planejamento de Transporte, 1999b).

No início dos anos 80, o Brasil deixava de ser um país exportador de matéria-prima para entrar no rol dos exportadores de manufaturados (Castro, 1988). As exportações de granéis continuaram sua trajetória de crescimento, principalmente com os investimentos no Complexo Carajás, que começava a dar seus primeiros resultados. Se o objetivo era resolver os problemas estruturais no Balanço de Pagamentos, esse novo cenário demandava constante renovação e ampliação da frota mercante nacional, o que minimizaria os gastos com "fretes". Todavia, essa não foi a tônica da década de 1980, que se cristalizou como uma "década perdida", principalmente para a Marinha Mercante e a construção naval brasileira.

Dado os atrasos na entrega das encomendas, a alta inadimplência dos armadores e dos construtores, que esta- vam abarrotados de dívidas com a SUNAMAM, e cuja situação se tornava insustentável, foi baixado o Decreto n. 88.420, de 21 de junho de 1983, que redefiniu as atribuições daquela Superintendência. Basicamente foi mudado o mecanismo de financiamentos, criando-se o Conselho Diretor do Fundo da Marinha Mercante (CDFMM), que ficaria responsável pela liberação dos próximos empréstimos. Os recursos arrecadados pela Adicional ao Frete para a Renovação da Marinha Mercante (AFRMM, antigo TRMM), base do FMM, seriam gerenciados apenas pelo BNDES, com autorização do CDFMM, ou seja, foi retirada a capacidade da SUNAMAM de liberar recursos aos estaleiros e aos armadores. Esse decreto foi o prelúdio de uma crise e de um escândalo financeiro que se ia instalar na SUNAMAM.

No final do governo João Figueiredo, foram descobertas várias irregularidades nos repasses de recursos da SUNAMAM para os construtores navais. Mesmo assim, mergulhada em dívidas, a autarquia avalizava os estaleiros para descontar duplicatas na rede bancária e continuar a construir os navios encomendados. Em 1984, o governo não reconheceu o aval da SUNAMAM e deu início a uma apuração das irregularidades, que ficaram conhecidas como o "Escândalo da SUNAMAM". Na época, estimava-se que as perdas para os cofres públicos foram de 545 milhões de dólares. Desse total, 290 milhões de dólares eram dívidas do Estaleiro Mauá, o que até resultou no suicídio do seu proprietário, o empresário Paulo Ferraz (Senado Federal, 1986).

A SUNAMAM, poderosa autarquia com ampla margem de manobra financeira e administrativa, tornou-se um estorvo para o governo federal e alvo de uma Comissão Parlamentar de Inquérito (CPI) no Congresso Nacional, em março de 1985. Após 14 meses de trabalho, o Relatório Final da CPI apresentou a seguinte conclusão básica: 
A construção naval e a Marinha Mercante brasileira foram acarretadas por uma política econômica que onerou financeiramente o setor, eliminou o aporte de recursos governamentais, restringiu as fontes de receitas próprias da SUNAMAM, bem como a capacidade de tomar empréstimos, além de haver substituído crescentemente as encomendas à indústria naval nacional por navios importados. $O$ governo anterior importou navios em volume suficiente para manter nossa indústria naval funcio-

nando durante um ano inteiro (Senado Federal, 1986, p. 5).

A recomendação do Relatório Final era de que fosse elaborada uma nova política que fortalecesse ambos os setores, além de promover "efetiva democratização da SUNAMAM, a fim de evitar eventuais desvios" (Senado Federal, 1986, p. 6). O escândalo atingiu diretamente a navegação e o setor naval, que viu suas encomendas encolherem, e os elos da cadeia inter-relacionada difusora de inovação foram quebrados. Na tabela abaixo, podemos acompanhar o volume total de embarcações contratadas pelo CDFMM no período de 1983 a 1989, distribuído por estaleiro. O que mais chamou a atenção foi a reduzida participação dos estaleiros nacionais, outrora tão beneficiados no volume total de contratações. No I e no II PCN, o Estaleiro Mauá participou com 18,2\% e 16,4\%, respectivamente, das encomendas; no entanto, com a atuação do CDFMM, a sua participação passou para 3,3\%, significando alta capacidade ociosa e desemprego. A crise na SUNAMAM e na economia brasileira atingiu diretamente a Marinha Mercante e os estaleiros, cujos empresários estavam desmoralizados por causa dos escândalos políticos.

A crise desencadeou um processo de reestruturação patrimonial com a compra, em 1983, do Estaleiro Verolme pela RSV, empresa de capital nacional que atendia mais às demandas das Forças Armadas brasileiras; o Estaleiro Emaq
Tabela 8_Contratações realizadas pela CDFMM nos principais estaleiros para o mercado interno 1983-1989

\begin{tabular}{|c|c|c|}
\hline Estaleiros & $\begin{array}{l}\text { Embarcações contratadas } \\
\text { (em TPB) }\end{array}$ & Participação (em \%) \\
\hline Verolme & 1.991 .849 & 54,5 \\
\hline Ishibrás & 1.218 .910 & 33,3 \\
\hline Caneco & 231.930 & 6,3 \\
\hline Mauá & 120.000 & 3,3 \\
\hline Emaq & 96.000 & 2,6 \\
\hline Total & 3.658 .689 & 100,0 \\
\hline
\end{tabular}

Fonte: Departamento da Marinha Mercante; Geipot, $1999^{\mathrm{a}}$.

foi incorporado pelo Grupo Sequip em 1986, que, mais tarde, veio a ser adquirido pelo Verolme; e o Estaleiro Mauá teve suas atividades quase desativadas por completo, em razão de seu envolvimento político com a SUNAMAM (Empresa Brasileira de Planejamento de Transportes, 1999a).

No início do governo Sarney, e seguindo as orientações da CPI, foi elaborada pelo Ministério dos Transportes a Política Nacional de Navegação Marítima Mercante, que apresentava nova proposta para o setor naval e a navegação, reafirmando o caráter nacional, e reforçava a importância do CDFMM, em vez daquela atribuída à SUNAMAM (Ministério dos Transportes, 1986a). No Programa de Desenvolvimento do Setor Transportes 1986-1989 (Prodest), que envolvia todas as autarquias ligadas ao Ministério dos Transportes, a SUNAMAM, que agonizava, assumia caráter mais normativo e fiscalizador (Ministério dos Transportes, 1986b).

No final da década de 1980, as mudanças administrativas e no padrão de financiamento da SUNAMAM rebateram na indústria da construção naval, que operava com capacidade ociosa de quase 60\%, empregando 17.965 trabalhadores, e na navegação nacional, cuja participação de navios com bandeira brasileira passou para 35,0\%, em 1989. Mesmo assim, muitos armadores resistiram ao rápido desmonte parcial do setor (Anexos 1 e 2). A frota do Lloyd Brasileiro, 
que frequentava em torno de 250 portos em todos os continentes, entrou num acelerado processo letárgico.

O desfecho final para a SUNAMAM veio com a Medida Provisória n. 27, de 15 de janeiro de 1989, que extinguiu 14 órgãos da administração federal, cujas competências foram transferidas para a recém-criada Secretaria de Transportes Aquáticos (STA), reforçando o caráter apenas normativo e fiscalizador daquela Superintendência no setor da navegação.

O Brasil chega ao final dos anos 80 numa crise econômica com profunda instabilidade nas finanças públicas $\mathrm{e}$ nos preços, sem capacidade para financiar a retomada do crescimento. O Estado estava politicamente desmoralizado, engessado numa crise fiscal e financeira, que imobilizara os instrumentos de planejamento. $\mathrm{O}$ endividamento externo crescia de forma exponencial, esvaziando os canais de financiamentos externo e interno, atrofiando as estatais, que, ao invés de auxiliá-las para a retomada do crescimento, foram eleitas pelos liberais como as anátemas da sociedade (Carneiro, 2002). É nesse clima que a SUNAMAM foi extinta, e a construção naval, parcialmente desmontada.

\section{5_Experiências históricas na América Latina}

O objeto deste item é fazer uma breve trajetória da Marinha Mercante e da construção naval na América Latina, com destaque para Chile, Argentina, Uruguai e México, mostrando a atuação do Estado e do capital nacional. Nesta breve trajetória, podemos identificar várias semelhanças com o Brasil, o que revela que imperou "certo modelo" de industrialização para a América Latina, entre 1930 e 1980.

No Chile, uma das primeiras grandes companhias de navegação que começou a frequentar os principais portos chilenos (Valparaíso, Antofagasta e Punta Arenas) foi a empresa inglesa Pacific Steam Navigation Company, que entrou em operação em 1838. Dois anos após, foi criada a
Companhia Nacional de Vapores, pertencente a capitalistas locais, que, inclusive, atuava na navegação fluvial. As pequenas companhias regionais cobriam espaços restritos e não alcançavam os grandes portos. Mais tarde, em 1870, foi fundada a Companhia Chilena de Vapores, outra grande companhia nacional.Ambas concorriam com a Pacific, que tentava monopolizar o transporte de cabotagem e de longo curso. Para enfrentar essa concorrência, em 1872, as duas companhias nacionais se fundiram e formaram a Companhia Sul Americana de Vapores (CSAV). A CSAV começou a ser subvencionada pelo governo chileno e ampliou sua área de atuação, deslocando a Pacific do mercado local. Nesse momento, a Marinha Mercante nacional já estava protegida na forma de lei, aprovada em 1878, que garantia uma "reserva de mercado". Durante todo o século XX, a CSVA tornou-se o símbolo da Marinha Mercante chilena, atendendo toda a costa do país e alcançando os principias portos no mundo. Atualmente a CSVA, que foi adquirida pelo capital externo, é uma das maiores empresas de navegação do mundo (Muñoz Gomá, 1986; Salazar, 2003).

Na construção naval chilena, ainda no século XVIII e início do XIX, os primeiros estaleiros de reparo e construção de pequenas embarcações de madeira localizam-se nas proximidades do porto de Valparaíso. Foi nesse porto que, em 1857, 1864 e 1875, foram construídos diques flutuantes para atender às demandas da frota naval militar e mercante. Em 1895, foi estabelecido o Arsenal da Marinha na Bahia de Talcahuano, em Concepcíon. Em 1900, em Punta Arenas, por iniciativa privada, foi montado um estaleiro naval. Contudo, a situação da indústria naval chilena deu um salto em 1960 com a criação do Astilleros y Maestranzas de La Armada (Asmar), empresa autônoma do Estado destinada a atender às demandas da Marinha de Guerra e Mercante do Chile. A Asmar é composta de três grandes plantas industriais, uma localizada em Valparaíso, outra, em Talcahuano, e outra, em 
Punta Arenas, ou seja, o Estado encampou os estaleiros privados e formou grande unidade estatal (Fritz, 2005).

Atualmente, também se destaca o Astillero Marco Chilena, de capital privado, localizado no norte do país, em Iquique, fundado em 1960, que atua na construção de embarcações para pesca costeira e oceânica.

$\mathrm{Na}$ Argentina, país de vasta extensão territorial e litorânea, com grande planície onde caudalosos rios navegáveis integram espaços territoriais, desenvolveu-se uma grande Marinha Mercante ligando Buenos Aires até a Terra do Fogo, e fluvial em direção ao centro e ao norte do país, sobretudo no Rio Paraná (Luis, 1938).

No final do século XIX e início do XX, a navegação argentina esteve ligada a Nicolas Mihanovich, que praticamente monopolizou o transporte aquático por meio de suas companhias de navegação. A Sociedade de Navegação a Vapor Nicolas Mihanovich contava com uma frota de aproximadamente 200 embarcações e atendia, inclusive, ao comércio uruguaio. Abrangia todo o espaço desde a navegação fluvial até o Mato Grosso, no Brasil, e Cabo Hornos, no extremo sul da Patagônia. Numa fusão com uma importante companhia inglesa, em 1909, foi fundada a The Argentina Navigation Company, que, aos poucos, foi sendo desnacionalizada. Após novas reestruturações, assume o comando um destacado funcionário de Mihanovich, chamado Alberto Dodero. No período de 1920 a 1940, Dodero dominará o cenário argentino no setor da navegação com a Companhia Argentina de Navegação Dodero e Rio da Prata e a Companhia de Navegação Fluvial (Bosch, 1962).

Em 1941, com a expropriação de embarcações alemãs nos portos locais, foi criada pelo governo a Frota Mercante do Estado, composta de 16 navios. Em 1951, durante o governo de Juan Domingos Perón, foi encampada toda a frota de Alberto Dodero. Mais tarde, como resultado da política de expansão estatal sobre a navegação, foi criada, em 1960, a Empresas Linhas Marítimas Argentinas (Elma), que passou a ditar os rumos da navegação no país, até os anos 90, quando foram todas privatizadas (Dorfman, 1983).

$\mathrm{Na}$ década dos anos 60, foram criados o Conselho Nacional da Marinha Mercante e o Fundo Nacional da Marinha Mercante, e ambos se converteram em duas alavancas de estímulo e fortalecimento das atividades navais na Argentina com forte caráter nacional (Ferrer, 2008).

A frota de YPF (Yacimientos Petrolíferos Fiscales), empresa criada em 1922, começou a montar sua frota de petroleiros ainda em 1929, mas foi em 1950 e 1960 que ampliou consideravelmente suas atividades marítimas. Nos anos 90, com o advento do neoliberalismo, toda a frota estatal mercante foi desativada ou privatizada. Com destaque para a venda da YPF em 1999 (Romero, 2006).

A trajetória da construção naval na Argentina teve início com a concentração de pequenos estaleiros de reparos próximo ao porto de Buenos Aires. Com a criação do Arsenal Naval Buenos Aires, acelerou-se o ritmo de atividades das oficinas navais que prestavam serviços de reparos. Após a criação da YPF, foi fundado o Astarsa, grande estaleiro privado que se encarregava de prestar serviços para a estatal petrolífera. Nos anos 30, foram criados os Astelleiros y Fábrica Navales del Estado, que quase monopolizaram as atividades industriais do setor. Com a criação da frota estatal, o estaleiro concentrou seus esforços em atender à crescente demanda do Estado.

Num panorama geral dos estaleiros na Argentina, podemos apontar o Astilleros Corrientes, fundado em 1958; o Astilleiro Mestrina, de 1965; o Astilleiro Ministro Manuel Domecq Garcia, de 1980; e o mais destacado, o Astileiro Rio Santiago, de 1953, que se converteu, em 1993, numa companhia estatal. Também se destacam alguns pequenos estaleiros na região de Mar de Plata que atuam na fabricação de barcos pesqueiros (Dorfman, 1983). 
No Uruguai, a Marinha Mercante sempre esteve muito associada à expansão das atividades navais da Argentina. Primeiro foi com a presença da Sociedade de Navegação a Vapor Nicolas Mihanovich, depois com a Companhia Argentina de Navegação Dodero e Rio da Prata. Os empresários uruguaios dedicavam-se mais à navegação de pequeno porte. Dodero criou a Companhia Uruguaia de Navegação em 1937. Durante a Primeira Guerra, o governo uruguaio encampou os navios alemães que estavam ancorados no porto de Montevidéu e formaram a empresa estatal Marina Mercante Ultramar.

Na construção naval, próximo ao porto de Montevidéu, no final do século XIX, surgiram as primeiras oficinas navais, que perduram por todo o século $\mathrm{XX}$, atuando nas atividades de reparo e manutenção. Destacaram-se os estaleiros Astilleiros Carmelos, de 1923, e a Metalúrgica e Diques Flutuante (MDF), de 1944. O estaleiro Carmelo, que pertencia ao empresário argentino Dodero, com a sua crise nos anos 40, foi incorporado pela Direção Nacional Hidrográfica, vinculada ao Ministério dos Transportes e Obras Públicas (Bertola, 2000; Finch, 2005).

Durante o período em que Porfírio Diaz esteve no poder, de 1876 a 1911, o México passou por rápida modernização dos transportes com a formação de ampla rede ferroviária, melhoramentos de alguns portos e criação de Companhias de Navegação de Cabotagem de longo curso. Em todos os setores, porém, havia forte presença do capital externo, marcando profundamente esse período liberal. Nos primeiros anos da década de 1880, foram criadas as seguintes companhias: Transatlântica Mexicana, Companhia Mexicana de Navegação, Companhia Naviera de Romano e Companhia Naviera do Pacífico. Também havia as pequenas companhias que faziam a cabotagem regional e ficavam mais a cargo de empresas de capital local. Toda a cabotagem mexicana estava aberta para o capital externo (Connolly, Kuntz, 1999).
Os portos de Veracruz, Manzanillo e Tampico foram os mais beneficiados com os melhoramentos realizados pelo governo de Porfírio Diaz, sendo que, em cada grande área portuária, se desenvolveram pequenos estaleiros que prestavam serviços às embarcações atracadas nos trapiches (Damian, 2008).

A Revolução de 1910, seguida da Constituição de 1917, alterou o quadro político e institucional no México. Com base nos Princípios Básicos do Direito Marinho Mexicano, o privilégio da cabotagem ficou garantido apenas às companhias nacionais. Também foi criada a Direção da Marinha Mercante, que passou a integrar a Secretaria de Comunicação e Transportes (Cruces, 1999).

Nas décadas dos anos 1930 e 1940, sobretudo durante o governo de Lázaro Cárdenas, a economia mexicana atravessou profundas mudanças, como a ampliação das funções do Estado no setor produtivo. O petrolífero foi nacionalizado, criando-se a Petróleos Mexicanos S.A. (Pemex), que encampou toda a frota petroleira. Iniciou-se a construção da Altos Hornos de México (AHMSA). Criou-se a Ferrocarriles Nacionales de México (FNM), que centralizou todos os sistemas ferroviários, além de outras intervenções estatais no setor produtivo. Para a Marinha Mercante, foi criado um Departamento Autônomo, que ampliou seu poder e sua capacidade de atuação. Destaca-se também a construção do primeiro dique seco do país, o San Juan de Ulúa, localizado em Veracruz, que possibilitou a formação de uma indústria naval mais pesada (Salinas, 1994).

Em 1946, a Pemex passa a atuar também no transporte marítimo, estimulando fortemente a nascente indústria naval mexicana, que já contava com uma grande siderurgia fornecedora de aço, a AHMSA.Em 1949, é criada a Companhia de Serviços Marítimos, com a participação estatal. Os portos de Tampico e Ensenada foram ampliados. Nos anos 50, foi elaborado o Programa de Progresso Marítimo, conheci- 
do como "Marcha al mar", cujos objetivos eram: promover um deslocamento demográfico em direção ao litoral, fortalecer o transporte marítimo, consolidar os estaleiros e melhor aproveitar os recursos marítimos (Guajardo, 2008). Dentro desse programa, foram criadas a Transporte Marítima Mexicana e a Companhia Marítima Mexicana, ambas com forte apoio financeiro estatal. $\mathrm{Na}$ área portuária, foi construído o porto Lázaro Cárdenas, no Pacífico, para atender ao comércio com a Ásia (Solis, Sotomayor, 2004).

Em 1980, a industrial naval mexicana estava numa fase madura, com a presença de vários estaleiros estatais atendendo à Marinha de Guerra e à Marinha Mercante nacional, formada pelo seguinte complexo:

No Golfo de México:

- Astillero de Marina 1 (ASTIMAR 1), em Tampico, Tamaulipas;

- Astillero de Marina 3 (ASTIMAR 3), em Coatzacoalcos, Veracruz.

- Astillero de Marina 6 (ASTIMAR 6), em Guaymas, Sonora;

- Astillero de Marina 18 (ASTIMAR 18), em Acapulco, Guerrero;

- Astillero de Marina 20 (ASTIMAR 20), em Salina Cruz, Oaxaca.

Nesse mesmo ano, foi aprovada a Lei para o Desenvolvimento da Marinha Mercante Mexicana, protegendo ainda mais o setor de navegação, elevando a participação da bandeira nacional no comércio de longo curso. Esses avanços no setor da navegação mexicana combinaram com o início da crise da dívida em 1982, que levou o governo a pedir moratória internacional e estatizar todo o sistema bancário. Os anos 80 inauguraram uma nova fase para a economia mexicana, cujas elevadas taxas históricas de crescimento foram bruscamente reduzidas, prejudicando todo o parque industrial.

\section{6_Conclusão}

Uma das características da indústria da construção naval pesada nos países de industrialização tardia é a sua dependência das políticas industriais e do financiamento de longo prazo, ambos sustentados pelo Estado. No Brasil, a sua consolidação e a sua expansão estiveram associadas ao Plano de Metas, quando foram criados outros mecanismos políticos, Geicon, e de financiamento, FFM e TRMM, associados à atração de dois grandes estaleiros externos e à seleção dos nacionais para serem incluídos nos planos de expansão. Durante a execução do Plano de Emergência e dos PCN I e II, de 1968 a 1980, tivemos uma fase de grande expansão, coordenada pela SUNAMAM e por encomendas estatais (Petrobras, CSN, Docenave, Lloyd Brasileiro e outras). Até esse momento, havia maior presença do Estado e formou-se um aglomerado inter-relacionado incorporando e difundido inovações para a indústria naval brasileira.

Quando o Brasil chegou a ser considerado o segundo maior construtor naval do mundo, em 1980, iniciou-se o arrefecimento do aglomerado. Na primeira metade dos anos 80, quando a SUNAMAM ficou mergulhada num escândalo político, os recursos financeiros começaram a se exaurir, presenciando-se o crescimento na capacidade ociosa e do endividamento dos estaleiros. A redução da participação do Estado foi prontamente sentida, prejudicando a capacidade inovadora e difusora da indústria naval brasileira.

Na segunda metade dos anos 80, a ausência do Estado agravou ainda mais a situação do setor, que chegou a uma capacidade ociosa de 60,0\%. Sem grandes encomendas e parcos recursos financeiros, assistimos ao início do desmonte parcial da indústria brasileira da construção naval pesada, que se reverteria, somente a partir de 2003, com a volta da ação política estatal. 


\section{Leis e decretos}

BRASIL. Decreto n ${ }^{\circ} 3.100$, de 07 de março de 1941. In: Senado Federal. Brasília. Disponível em: $<$ http://www6.senado.gov.br/ sicon>. Acesso em: 14 mar. 2008.

BRASIL. Decreto ${ }^{\circ}$ 64.125, de 19 de fevereiro de 1969. In: Senado Federal. Brasília. Disponível em: $<$ http://www6.senado.gov.br/ sicon>. Acesso em: 14 mar. 2008.

BRASIL. Decreto no 67.992, de 30 de dezembro de 1970. In: Senado Federal. Brasília. Disponível em: $<$ http://www6.senado.gov.br/ sicon>. Acesso em: 14 mar. 2008.

BRASIL. Decreto ${ }^{\circ} 73.838$, de 13 de março de 1974. In: Senado Federal. Brasília. Disponível em: $<$ http://www6.senado.gov.br/ sicon>. Acesso em: 14 mar. 2008.

BRASIL. Decreto no 88.420 , de 21 de junho de 1983. In: Senado Federal. Brasília. Disponível em: $<$ http://www6.senado.gov.br/ sicon>. Acesso em: 14 mar. 2008.

BRASIL. Lei no ${ }^{\circ} 3.381$, de 24 de abril de 1958. In: Senado Federal. Brasília. Disponível em: <http:// www6.senado.gov.br/sicon>. Acesso em: 14 mar. 2008.
BRASIL. Medida Provisória no 27 , de 15 de janeiro de 1989. In: Senado Federal. Brasília. Disponível em: $<$ http://www6.senado.gov.br/ sicon>. Acesso em: 14 mar. 2008.

\section{Planos, relatórios e documentos oficiais}

BRASIL. I Plano Nacional de

Desenvolvimento 1972-1974. Brasília: Presidência da República, 1971.

BRASIL. II Plano Nacional de Desenvolvimento 1975-1979. Brasília: Presidência da República, 1974.

BRASIL. III Plano Nacional de Desenvolvimento 1980-1985. Brasília: Presidência da República, 1980.

COMISSÃO MISTA BRASILESTADOS UNIDOS. Relatório Geral. Rio de Janeiro, tomo 1, 1954.

COMISSÃO DA MARINHA MERCANTE. Relatórios das atividades da Comissão da Marinha Mercante. Rio de Janeiro, 1956-1966.

\section{CONSELHO DE}

DESENVOLVIMENTO.

Reaparelhamento da Marinha Mercante. Rio de Janeiro: Presidência da República, doc. n. 2, 1956.
CONSELHO DE

DESENVOLVIMENTO. Plano

de Metas. Rio de Janeiro:

Presidência da República, 1958.

EMPRESA BRASILEIRA

DE PLANEJAMENTO DE

TRANSPORTES. Estudo sobre construção naval. Brasília:

Ministério dos Transportes, 1982.

EMPRESA BRASILEIRA

DE PLANEJAMENTO DE

TRANSPORTES. Política

governamental e competitividade da

indústria brasileira de construção

naval: Evolução, estrutura e

diagnóstico. Brasília: Ministério

dos Transportes, v. 2, 1999a.

EMPRESA BRASILEIRA

DE PLANEJAMENTO DE

TRANSPORTES. Política

governamental e competitividade

da Marinha Mercante brasileira.

Brasília: Ministério dos

Transportes, v. 3, 1999b.

MINISTÉRIO DA VIAÇÃO E

OBRAS PÚBLICAS. Grupo Executivo

da Indústria de Construção Naval -

GEICON. Rio de Janeiro: Serviço de Documentação, 1958.

MINISTÉRIO DA VIAÇÃO E OBRAS PÚBLICAS. Sumário das atividades 1965-66. Brasília, 1967.
MINISTÉRIO DOS TRANSPORTES.

0 Ministério dos Transportes na integração e desenvolvimento nacional. Rio de Janeiro: Serviço de Documentação, 1968.

MINISTÉRIO DOS TRANSPORTES. Politica Nacional de Navegação e Marinha Mercante. Brasília, 1986a.

MINISTÉRIO DOS TRANSPORTES. Programa de Desenvolvimento do Setor Transportes 1986-1989. Brasília, 1986b.

SENADO FEDERAL. CPI

SUNAMAM: Relatório final da comissão. Brasília: Imprensa Oficial, 1986.

SINDICATO DA INDÚSTRIA DA CONSTRUÇÃO NAVAL DO RIO DE JANEIRO. A indústria de construção naval do Brasil. Rio de Janeiro: SINAVAL, 1962.

\section{SOCIEDADE BRASILEIRA DE}

ENGENHARIA NAVAL. Anais da III Semana de Estudos Sobre Transportes Marítimos e Construção Naval. Rio de Janeiro, 1962.

SUPERINTENDÊNCIA NACIONAL DA MARINHA MERCANTE.

Anuário da Marinha Mercante.

Rio de Janeiro, 1968-1985.

(Série completa) 


\section{Livros, dissertações e teses}

ARAÚJO JÚNIOR, José Tavares de, et al. A indústria de construção naval no Brasil: Desempenho recente e perspectiva. Rio de Janeiro: UFRJ/IE, 1985.

BARAT, Josef. O setor de transportes. In: AFFONSO, Rui de B. A., SILVA, Pedro L (Orgs.). Federalismo no Brasil: Empresas estatais e federação. São Paulo: FUNDAP, 1996.

BRACONNOT, C. P. Possibilidades da construção naval pela indústria particular. In: FLEMING, Thiers. A construção naval no Brasil. Rio de Janeiro: Jornal do Comércio, 1936.

BERTOLA, Luis. Ensayos de historia económica: Uruguay y la región en la economía mundial 1870-1990. Montevideo: Trilce, 2000.

BOSCH, Felipe. Historia naval argentina. Buenos Aires:

Alborada, 1962.

BRANDO, Pedro. Por que não temos construção naval? Rio de Janeiro: Pongetti, 1958.

CARNEIRO, Ricardo.

Desenvolvimento em crise: A economia brasileira no último quarto do século XX. São Paulo: Unesp; IE/Unicamp, 2002.

CASTRO, Antonio Barros de. Ajustamento $x$ transformação: A economia brasileira de 1974 a 1984. In: CASTRO, Antonio Barros de, SOUZA, Francisco Eduardo Pires. A economia brasileira em marcha forçada. São Paulo:

Paz e Terra, 1988.
CONNOLLY, Priscilla; KUNTZ, Sandra (Orgs.). Ferrocarriles $y$ obras públicas. Cidade do México: Instituto Mora, 1999.

COSTA, Jorge Gustavo da. Planejamento governamental: A experiência brasileira. Rio de Janeiro: FGV, 1971.

CRUCES, Alfonso Fernandez. La marina mercante nacional como base de desarrollo de la industria naval. 1999. Tese (Doutorado em Economia) UNAM, Cidade do México, 1999.

DAMIAN, Jorge Jesús Morales.

El desarrollo de la marina mercante, como actividad prioritaria del Estado Mexicano. 2008. Tese (Doutorado em Economia) - UNAM, Cidade do México, 2008.

DRAIBE, Sônia Miriam. Rumos e metamorfoses: Um estudo sobre a constituição do Estado e as alternativas da industrialização no Brasil 1930-1960. Rio de Janeiro: Paz e Terra, 1985.

DORFMAN, Adolfo. Cincuenta años de industrialización en la Argentina 1930-1980. Buenos Aires: Solar, 1983.

FERRER, Aldo. La economía argentina. Fundo de Cultura Económica: Buenos Aires, 2008.

FINCH, Henry. La economía politica del Uruguay contemporáneo 1870-2000.

Montevideo: Ediciones de la Banda Oriental, 2005.

FRITZ, Carlos Martin. ASMAR: Su contribución a la industria naval en Chile. Viña del Mar: Orgraf, 2005.
GOULARTI FILHO, Alcides.

História econômica da construção naval no Brasil: Formação de aglomerado e performance inovativa. In: ENCONTRO NACIONAL DE ECONOMIA, 37., 2009, Foz do Iguaçu. Anais... In: ENCONTRO NACIONAL DE ECONOMIA, 37., Niterói Anais... Niterói: ANPEC, 2009a. v. 37 .

GOULARTI FILHO, Companhia de Navegação Lloyd Brasileiro: Uma trajetória de déficit financeiro e desenvolvimento econômico. In: História Econômica \& História de Empresas, v. 13, p. 2545, 2009b.

GRASSI, Robson Antonio. A indústria naval brasileira no período 1958-1994: Uma análise histórica de sua crise atual e da perspectiva de mudança a partir do conceito estrutural de competitividade. Niterói: UFF, 1995 .

GREENHALGH, Juvenal. 0 arsenal de Marinha do Rio de Janeiro na história 1822-1889. Rio de Janeiro: IBGE, 1965.

GUAJARDO, Guillermo (Org.). Innovación y empresa: Estudios históricos de México, España y América Latina. Cidade do México: CEIICH-UNAM, 2008.

GUIMARÃES, José Celso de Macedo Soares. Navegar é preciso: Crônicas de muitas lutas as lutas. Rio de Janeiro: Rio Fundo, v. 1, 1996.

LESSA, Carlos. Quinze anos de política econômica. São Paulo: Brasiliense, 1982.
LUIS, Ario Russo. La marina mercante argentina. Buenos Aires: Porter, 1938

MENDONÇA, Mário F.; VASCONCELOS, Alberto Repositório de nomes dos navios da esquadra brasileira. Rio de Janeiro: SDGM, 1959 .

MUNÕZ GOMÁ, Óscar. Chile y su industrialización: Pasado, crisis y opciones. Santiago: CIEPLAN, 1986.

NELSON, Richard R. As fontes do crescimento econômico. Campinas: Editora da Unicamp, 2006.

PERROUX, Francois. A economia do século XX. Lisboa: Helder, 1967.

ROMERO, Luis Alberto. História contemporânea da Argentina. Rio de Janeiro: Jorge Zahar Editor, 2006.

ROSENBERG, Nathan. Por dentro da caixa preta: Tecnologia e economia. Campinas: Editora da Unicamp, 2006.

SALAZAR, Gabriel. Historia de La acumulación capitalista en Chile: Apuntes de clase. Santiago: LOM Ediciones, 2003.

SALINAS, Samuel. Historia de los caminos de México. Cidade do México: Banco Nacional de Obras y Servicios Públicos, 1994.

SOLIS, Maria Alejandra Ayla; SOTOMAYOR, Suzana Gonsalez. Marina mercante, sistema marítimo portuário como factor y via de desarrollo econômico para México. 2004. Tese (Doutorado em Economia) - UNAM, Cidade do México, 2004. 
TAVARES, Maria da

Conceição. Acumulação de

capital e industrialização no Brasil.

Campinas: UNICAMP/IE, 1998.

TAVARES, Maria da Conceição, BELLUZZO Luiz Gonzaga de

Mello. Notas sobre o processo

de industrialização recente

no Brasil. In: BELLUZZO, Luiz

Gonzaga de Mello, CoUTinHo,

Renata (org.). Desenvolvimento

capitalista no Brasil: ensaios sobre a

crise. São Paulo: Brasiliense, 1984.

E-mail de contato dos autores:

alcides@unesc.net

TELLES, Pedro Carlos da Silva.

História da construção naval do Brasil.

Artigo recebido em julho de 2011 e

Rio de Janeiro: FEMAR, 2001.

aprovado em fevereiro de 2012. 
Anexos

Anexo 1_Panorama da indústria da construção naval brasileira 1960-1989

\begin{tabular}{|c|c|c|c|c|c|c|c|}
\hline Anos & TPB (mil) & AFRMM (US\$ mil) & $\begin{array}{l}\text { Trabalhadore } \\
\text { construção naval }\end{array}$ & Anos & TPB (mil) & AFRMM (US\$ mil) & $\begin{array}{l}\text { Trabalhadores } \\
\text { construção naval }\end{array}$ \\
\hline 1960 & 1.300 & 25.885 & 1.430 & 1975 & 4.604 & 273.421 & 23.000 \\
\hline 1961 & 1.308 & 28.895 & 5.850 & 1976 & 5.098 & 240.326 & 25.000 \\
\hline 1962 & 1.355 & 30.354 & 7.350 & 1977 & 5.613 & 217.870 & 28.700 \\
\hline 1963 & 1.441 & 34.081 & 7.630 & 1978 & 6.176 & 277.586 & 31.000 \\
\hline 1964 & 1.424 & 25.875 & 10.900 & 1979 & 7.201 & 294.395 & 39.155 \\
\hline 1965 & 1.402 & 29.963 & 11.600 & 1980 & 8.069 & 409.402 & 33.792 \\
\hline 1966 & 1.422 & 34.988 & 12.500 & 1981 & 8.928 & 501.819 & 34.472 \\
\hline 1967 & 1.431 & 37.297 & 13.500 & 1982 & 9.384 & 436.029 & 33.469 \\
\hline 1968 & 1.711 & 33.677 & 15.000 & 1983 & 9.344 & 402.413 & 26.180 \\
\hline 1969 & 1.778 & 51.228 & 16.500 & 1984 & 10.001 & 516.262 & 21.000 \\
\hline 1970 & 2.339 & 69.317 & 18.000 & 1985 & 10.299 & 452.001 & 21.463 \\
\hline 1971 & 2.265 & 95.805 & 18.500 & 1986 & 10.599 & 562.273 & 18.796 \\
\hline 1972 & 2.560 & 122.318 & 19.200 & 1987 & 9.720 & 539.124 & 20.493 \\
\hline 1973 & 2.980 & 152.534 & 20.000 & 1988 & 9.551 & 514.623 & 19.277 \\
\hline 1974 & 4.110 & 300.746 & 21.500 & 1989 & 9.382 & 428.033 & 17.965 \\
\hline
\end{tabular}

Fonte: CMM; SUNAMAM; Sinaval. 
Anexo 2_Evolução da participação da bandeira brasileira na navegação de longo curso (exportação e importação) 1969-1989

\begin{tabular}{|c|c|c|c|c|c|}
\hline Anos & $\begin{array}{l}\text { Bandeira brasileira } \\
\text { Navios próprios }\end{array}$ & Navios afretados & Total & Bandeira estrangeira & Total \\
\hline 1969 & 8,1 & 22,3 & 30,4 & 69,6 & 100,0 \\
\hline 1970 & 12,9 & 21,7 & 34,6 & 65,4 & 100,0 \\
\hline 1971 & 12,3 & 24,9 & 37,2 & 62,8 & 100,0 \\
\hline 1972 & 12,3 & 29,6 & 41,9 & 58,1 & 100,0 \\
\hline 1973 & 10,5 & 34,8 & 45,3 & 54,7 & 100,0 \\
\hline 1974 & 11,4 & 31,0 & 42,4 & 57,6 & 100,0 \\
\hline 1975 & 12,2 & 33,1 & 45,3 & 54,7 & 100,0 \\
\hline 1976 & 10,8 & 36,0 & 46,8 & 53,2 & 100,0 \\
\hline 1977 & 11,6 & 39,3 & 50,9 & 49,1 & 100,0 \\
\hline 1978 & 12,8 & 38,8 & 51,6 & 48,4 & 100,0 \\
\hline 1979 & 12,9 & 35,7 & 48,6 & 51,4 & 100,0 \\
\hline 1980 & 14,4 & 35,2 & 49,6 & 50,4 & 100,0 \\
\hline 1981 & 18,6 & 27,8 & 46,4 & 53,6 & 100,0 \\
\hline 1982 & 20,3 & 28,1 & 48,4 & 51,6 & 100,0 \\
\hline 1983 & 19,0 & 25,6 & 44,6 & 55,4 & 100,0 \\
\hline 1984 & 17,0 & 25,4 & 42,5 & 57,5 & 100,0 \\
\hline 1985 & 17,3 & 20,5 & 37,7 & 62,3 & 100,0 \\
\hline 1986 & 19,0 & 22,0 & 40,9 & 59,1 & 100,0 \\
\hline 1987 & 16,3 & 24,7 & 41,0 & 59,0 & 100,0 \\
\hline 1988 & 15,8 & 22,4 & 38,2 & 61,8 & 100,0 \\
\hline 1989 & 15,0 & 20,0 & 35,0 & 65,0 & 100,0 \\
\hline
\end{tabular}

Fonte: SUNAMAM. 